\title{
Is ICT a Lever for Educational Change? A Study of the Impact of ICT Implementation on Teaching and Learning in Hong Kong
}

\author{
Emily M.L. WONG, Sandy C. LI \\ Department of Education Studies, Hong Kong Baptist University \\ Kowloon Tong, Hong Kong \\ e-mail:emilyw@hkbu.edu.hk, sandyli@hkbu.edu.hk
}

Received: May 2006

\begin{abstract}
The ongoing, unprecedented growth of ICT, coupled with the globalisation of the economy, has created a huge challenge for education. This rapid growth of infusing ICT in education is confronting stakeholders with the effectiveness and the impact of these technological applications. This paper explores the impact of ICT implementation on Hong Kong classroom practice since the inception of the government IT initiatives with particular emphasis on teachers' perceived changes in teaching and learning, and how it interacts with a variety of contextual factors such as leadership and school climate. To deepen our understanding of how ICT acts as a lever to bring about changes in student learning, this study also relates changes in learning to various factors like frequency and types of ICT tools used in classroom teaching, and the kinds of instructional strategies. It is hoped that the findings will inform educational practitioners and researchers of the emerging pedagogical practices with ICT.
\end{abstract}

Key words: ICT implementation, teaching and learning, school leadership.

\section{Introduction}

The ongoing, unprecedented growth of information and communication technology (ICT), coupled with the globalisation of the economy, has created a huge challenge for education. The common belief that ICT has the potential to support certain fundamental changes in learning has been guiding and shaping educational reforms (Panel On Education Technology, 1997). Many countries have already drawn up their master plans for the development of ICT in education. In Hong Kong, the commitment of promoting the application of ICT across the school curriculum was confirmed with the introduction of "Information Technology for Learning in a New Era: Five-year Strategy - 1998/99 to 2002/03" in 1998 (Education and Manpower Bureau, 1998).

Despite this, significant concerns have been raised with regard to whether ICT is simply reinforcing old pedagogy (Lankshear, Snyder, and Green, 2000; Papert, 1997), or even distracting the students from studying the subject matter (Oppenheimer, 2003). As indicated from the findings of the report "Preliminary Study on Reviewing the Progress and Evaluating the Information Technology in Education Projects, December 2000 to August 
2001" submitted to the Education and Manpower Bureau of HKSAR Government (Centre for Information Technology in School and Teacher Education, 2002), many schools regarded ICT in education as an effort to simply replace chalk and board by multimedia presentations/animations. Nevertheless, schools that had history and background in curriculum innovation and with a strong leadership, were able to describe a much wider range of plans for teaching and learning activities using ICT.

This suggests that pedagogical and organisational issues need to be addressed if ICT use is to go beyond fancy tools (Papert, 1997), or a kind of apolitical technology adoption lacking reflection on how ICT may change the social environment (Ferneding, 2003). Based on the data obtained from a questionnaire survey administered to around 1000 teachers coming from 130 schools, the present paper aims to explore the impact of ICT Implementation on Hong Kong classroom practice after the inception of the government ICT initiatives, with particular emphasis on teachers' perceived changes in teaching and learning, and how it interacts with a variety of contextual factors in an ecology of ICT implementation. The study addresses the following questions:

1. Has ICT implementation been effecting a change in pedagogy after the inception of the government ICT initiative?

2. If so, what is the change in pedagogical practices?

3. How does pedagogical practices relate to the modes of learning?

4. Do frequency and types of ICT tools used in classroom teaching relate to these changes?

5. What is the impact of school leadership and climate on these changes?

6. What are the factors conducive to the sustainability of change?

\section{Background}

Educational change. It has been believed that an understanding of how educational change takes place is vital to successful ICT implementation (Hall, 1995). A review of the literature on educational change and school reform has suggested that although educators/policymakers shared the same basic vision of effecting changes in student learning, they had divergence in the way of implementing the changes, with the extremes of mere emphasis on instructional methods in 1970s (Cheng, 2002), and of mere emphasis on restructuring without making connections between new governance structures and the teaching and learning process While acknowledging the core of educational change was best manifested by changes in the daily teaching and learning activities (Hall, 1995), education policymakers have begun to view educational change in a wider institutional context (McLaughlin, 1991). As a result of the widespread interest in studying educational change in an institutional context, many researchers have adopted an organisational approach to study the issue. Educational change was construed as changes in instructional practices and in the culture of teaching toward greater collaborative relationships among students, teachers and other potential partners (Fullan, 1993). At the same time, increasing attention has also been given to conceptualising educational policy implementation 
as a form of individual and organisational learning (Fullan, 1995; Hall and Carter, 1995; Senge et al., 2000).

In addition, the role of school leadership has been gaining increasing importance in the context of educational change (Leithwood, 1994). In 1980s, instructional leadership conceptualisation drawn from the effective school literature was dominant, with a leadership focusing on teachers' behaviours that related to activities directly affecting the growth of students (Leithwood and Duke, 1999). Since the 1990s, many researchers have adopted new perspectives in understanding school leadership other than an instructional leadership conceptualisation (Hallinger and Heck, 1998). Leadership has been conceptualised as an organisational quality that is embedded in a social and cultural context (Ogawa and Bossert, 1995), as an integration of transformational and instructional leadership (Marks and Printy, 2003). Anyway, the dominant model has been transformational leadership that focuses on increasing the organisation's capacity to innovate (Hallinger and Heck, 1998), and adopting a commitment-building strategy for school restructuring (Leithwood, 1994).

Conceptualisation of ICT implementation. How are the concepts of educational change related to the use of ICT in education? In a review of studies on ICT in education, it was found out that the focus has been shifted from studying particular technologies and their impact on student learning, to studying how technology is integrated into education settings (Honey, Culp, and Carrigg, 2000). While such progression indicates an increased awareness of viewing the use of ICT in context, conceptualisation of ICT implementation is still inadequate, in a sense that there is a lack of a holistic conceptualisation of ICT implementation that links the use of ICT to educational change. We suggest that answering these questions requires the re-conceptualisation of a range of concepts relevant to educational change: (1) effective use of ICT cannot be accomplished by technological fixes alone, instead it is embedded in the larger process of educational change; (2) effective use of ICT requires pedagogical intervention from teachers, which involves a conceptual change of teaching and learning from a teacher-centred approach to a student-centred approach; (3) effective use of ICT requires organisational intervention, which involves a conceptual change of leadership from instructional leadership to transformational leadership, and a conceptual change of professionalisation from teacher training to human and social capital development of teachers

If effective ICT use is embedded in a larger process of school change (Honey, Culp, and Carrigg, 1999), then effort of ICT implementation needs to be examined as part of multifaceted school reform rather than in isolation (Bober, 2002). Arguably, studies seeking to demonstrate the impact of particular software on student learning do not help much in this respect. In viewing ICT implementation as a process of interactions between implementers and their contextual factors with a view to targeting changes in student learning, this study attempts to bridge the research gap by constructing models to inspect how ICT implementation affect changes in teaching and learning, in particular the roles of a transformational leadership and a climate for collaboration and experimentation. 


\section{Sample and Procedure}

The current study worked on part of the data collected from a large scale questionnaire survey that covered multiple sources including school principals, heads of ICT team, subject panel chairmen, teachers and students. In this study, most of the analysis was conducted on the part of the quantitative data collected from teachers. Therefore, the data analysis largely represented the perception from teachers.

The working population was defined as the public primary and secondary schools in HKSAR, and all of them were invited to participate in the survey. Out of the working population, a total of 1076 teachers from 130 schools were recruited on voluntary basis, which was about one tenth of the school population. The recruited sample schools were located in all 18 school districts in Hong Kong. In terms of distribution according to finance types (government, direct-subsidy scheme, and aided), the sample population closely resembled the true population. Primary schools made up 53\% of the sample, and secondary schools $47 \%$, the distribution of which was quite similar to the true population (60\% primary schools and $40 \%$ secondary schools). To increase the representativeness, teachers in each school were selected from diversified subject domains including languages, mathematics, humanities, science, technology, art, and physical education. In each primary school, 10 teachers coming from specified subject domains were selected by schools to fill out the questionnaires; and in each secondary school, 9 teachers from specified subject domains were selected by schools to fill out the questionnaires.

\section{Research Framework and Data Analysis}

This paper explores the impact of ICT implementation on classroom practice, and how classroom practice interacts with a variety of contextual factors. To better conceptualise the ecology of ICT implementation in schools, five constructs namely leadership, school climate, ICT implementation, teaching, and learning are developed. Zero order correlation analysis is then performed to explore the association between the five constructs (Fig. 1). Finally, inferences are made from the results with the help of ANOVA, t-tests, and some other descriptive statistics, with particular reference to the impact of ICT on provoking changes in classroom practices.

\section{Measures}

There were five constructs to explore the impact of ICT implementation on classroom practice. On average, each scale was made up of about 6 items, with a total of 31 items on the whole. All items were measured on a 4-point Likert scale ranging from "strongly disagree" to "strongly agree", and a positive evaluation will result in higher scores.

Leadership. Conceptualisation of leadership was along the direction of transformational leadership in establishing shared visions and building innovative capacity. In this way, the leadership scale in this study measured the perceived school leadership with a 


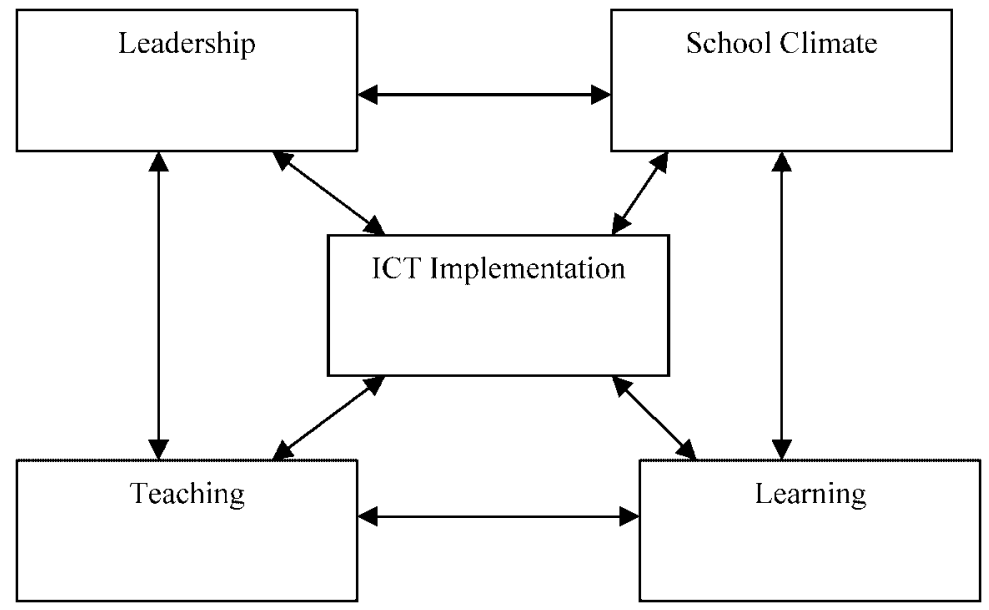

Fig. 1. Research framework investigating the interactions among the constructs in the ecology of ICT implementation in schools.

focus on measuring the school principal's transformational leadership in four domains: (1) the capability of establishing shared visions, (2) the capability of trusting and empowering teachers, (3) the capability of supporting innovations in classroom practices, and (4) the capability of supporting staff development (see Table 1).

School Climate. School climate has been described as the quality of a school that stimulates teachers' creativity, enthusiasm, and sense of belonging (Freiberg and Stein, 1999), in particular the collegial relationships (Reinhartz and Beach, 2004). As conceptualisation of school climate in the present study was along the direction of collaboration and experimentation, it also included the domains of striving for progress among teachers and flow of information within the school, in addition to the traditional domains of collegial relationships. In a context of transformational leadership, an open and efficient

\section{Table 1}

The leadership scale comprises of four domains of questions for measuring teachers' perceptions on their school principal's leadership

\begin{tabular}{|c|c|c|}
\hline Domain & Item & Questions \\
\hline \multirow[t]{2}{*}{ Establishing shared visions } & Ld1 & My educational beliefs are reflected in the school goals. \\
\hline & $\mathrm{Ld} 2$ & The school goals are reflected in school plans. \\
\hline \multirow[t]{2}{*}{ Trust and Empowerment } & $\mathrm{Ld} 3$ & The principal trusts me with school matters. \\
\hline & $\mathrm{Ld} 4$ & $\begin{array}{l}\text { Teachers have autonomy to make decisions relevant to their } \\
\text { teaching. }\end{array}$ \\
\hline Support for innovation & Ld5 & $\begin{array}{l}\text { The principal encourages me to experiment with new ideas in } \\
\text { classroom practice. }\end{array}$ \\
\hline \multirow[t]{2}{*}{ Support for staff development } & Ld6 & $\begin{array}{l}\text { My school provides adequate resources to support staff profes- } \\
\text { sional development. }\end{array}$ \\
\hline & $\mathrm{Ld} 7$ & The principal values staff professional development. \\
\hline
\end{tabular}


communication between school principals and teachers may help to establish a collaborative school climate with innovative capacity, and that's why the domain of flow of information within school was included here. The school climate scale of the present study measured among teachers their (1) collegial relationships, (2) their spirit to strive for progress, and also (3) the flow of information within school (see Table 2).

ICT Implementation. Conceptualisation of ICT implementation was along the direction of providing a supportive ICT context in schools that might offer collegial exchange of professional-development experiences that enhanced changes in pedagogical practices (Dexter, Anderson, and Becker, 2000; Zhao and Frank, 2003). While the supportive context might be in a direct manner of providing formal and informal channels of exchanging knowledge and ideas, it might also be an indirect one of capacity building in the form of pulling together human resources and experiences. Along this line of reasoning, the scale measured the capacity of the school's ICT implementation strategies in two domains: (1) enhancing a collegial exchange of ICT knowledge, and (2) enhancing the mobilisation of resources (see Table 3).

Teaching. Teaching and learning were conceptualised with reference to the HKSAR official document "Learning to Learn: Life-long Learning and Whole-person Development" (Curriculum Development Council, 2001). The scales measured the degree of paradigm shift in pedagogy and learning from a teacher-centred approach to a studentcentred approach over a period of two years' time, which was parallel to changes in classroom practices from a traditional approach to a constructivist approach. Apart from changes in classroom practice, it was believed that changes in curriculum content as well as changes towards a collaborative kind of teaching would enhance changes in pedagogy from a teacher-centred approach to a student-centred approach. Hence there were three domains indicating changes in pedagogy: (1) curriculum, (2) collaborative teaching, and (3) classroom practice. A positive evaluation will result in higher scores (see Table 4).

Learning. The learning construct measured the perception on whether students have adopted a more constructivist approach in learning over a period of two years' time. In addition to learning ability, it was suggested that students' attitude in learning as well as the learning process were also important (Curriculum Development Council, 2001). Hence the changes in learning scale focused in measuring the process of learning, in

Table 2

The school climate scale consists of three domains of questions: (1) collegial relationships, (2) their spirit to strive for progress, and also (3) the flow of information within school

\begin{tabular}{lll}
\hline Domain & Item & Questions \\
\hline Flow of information & $\mathrm{Cm} 1$ & I feel comfortable to talk to the principal about school matters. \\
& $\mathrm{Cm} 2$ & $\begin{array}{l}\text { My opinions can be conveyed to policy-making units (e.g., school man- } \\
\text { agement board/committees/departments) effectively within school. }\end{array}$ \\
Collegiality & $\mathrm{Cm} 3$ & $\begin{array}{l}\text { I have a sense of belonging to my school. } \\
\text { Striving for progress }\end{array}$ \\
& $\mathrm{Cm}$ Teachers in our school work in a collegial manner. & $\begin{array}{l}\text { Teachers in our school are willing to experiment with new ideas in class- } \\
\text { room practice. }\end{array}$ \\
\hline
\end{tabular}


Table 3

The ICT implementation scale measured the capacity of the school's ICT implementation strategies in two domains: (1) enhancing a collegial exchange of ICT knowledge, and (2) enhancing the mobilisation of resources

\begin{tabular}{|c|c|c|}
\hline Domains & Item & Questions \\
\hline \multirow[t]{4}{*}{ Mobilising resources } & Is 1 & $\begin{array}{l}\text { My school has a mechanism to disseminate the experiences of using ICT } \\
\text { resources for teaching and learning. }\end{array}$ \\
\hline & Is $2 *$ & The principal encourages teachers to experiment with new ICT practices. \\
\hline & Is 3 & $\begin{array}{l}\text { My school has mobilised resources from external parties (e.g., parents/ } \\
\text { alumni/ other schools/ organisations) to help to implement ICT in teach- } \\
\text { ing and learning. }\end{array}$ \\
\hline & Is $4 *$ & $\begin{array}{l}\text { The principal is willing to release teachers to attend train- } \\
\text { ing/workshops/conferences on using ICT in teaching and learning. }\end{array}$ \\
\hline \multirow[t]{4}{*}{$\begin{array}{l}\text { Collegial exchange } \\
\text { of ICT knowledge }\end{array}$} & Is5 & $\begin{array}{l}\text { Teachers' opinions can be conveyed to ICT policy-making bodies effec- } \\
\text { tively within school. }\end{array}$ \\
\hline & Is6 & $\begin{array}{l}\text { Colleagues in my school exchange experiences of using ICT to enhance } \\
\text { teaching and learning. }\end{array}$ \\
\hline & Is 7 & $\begin{array}{l}\text { I participate in sharing sessions for exchanging experiences (of using ICT } \\
\text { to enhance teaching and learning) with teachers from other schools. }\end{array}$ \\
\hline & Is8 & $\begin{array}{l}\text { I participate in sharing sessions for exchanging experiences (of using ICT } \\
\text { to enhance teaching and learning) with educators from tertiary institu- } \\
\text { tions. }\end{array}$ \\
\hline
\end{tabular}

Table 4

The teaching scale comprises three domains indicating changes in pedagogy: (1) curriculum, (2) collaborative teaching, and (3) classroom practice

\begin{tabular}{lll}
\hline Domains & Item & Questions \\
\hline Curriculum & Pd1 & $\begin{array}{l}\text { Compared to the past two academic years, our school curriculum is putting more } \\
\text { emphasis on infusing generic skills (e.g., critical thinking/creativity/ communi- } \\
\text { cation skills) into teaching and learning of various subjects. } \\
\text { Compared to the past two academic years, I am more willing to have collabora- } \\
\text { tive lesson preparation with my colleagues. } \\
\text { teaching }\end{array}$ \\
$\begin{array}{lll}\text { Classroom } \\
\text { practice }\end{array}$ & Pd4 & $\begin{array}{l}\text { Compared to the past two academic years, I am more willing to participate in } \\
\text { peer classroom observation. } \\
\text { Compared to the past two academic years, I am creating more opportunities for } \\
\text { discussions to develop students' expressive and analytical abilities. } \\
\text { Compared to the past two academic years, I am encouraging students to explore } \\
\text { and to inquire in learning more. } \\
\text { Compared to the past two academic years, I am providing more opportunities } \\
\text { for students to determine their learning activities. }\end{array}$ \\
\hline
\end{tabular}

which the learning ability and attitude were both considered. Learning ability was concerned with competency in generic skills and active learning, whereas learning attitude was concerned with demonstrating motivation and enthusiasm in the process of learning. In this way, perceived changes in student learning captured domains of (1) learning ability and, (2) learning attitude (see Table 5). 
Table 5

The questions of the learning scale fall into two domains: (1) learning ability and, (2) learning attitude

\begin{tabular}{|c|c|c|}
\hline Domains & Item & Questions \\
\hline \multirow[t]{4}{*}{$\begin{array}{l}\text { Learning ability: } \\
\text { generic skills and } \\
\text { active learning }\end{array}$} & $\operatorname{Ln} 1$ & $\begin{array}{l}\text { Compared to students of the same level in the past two academic years, my } \\
\text { students are more competent in mastering various generic skills (e.g., col- } \\
\text { laboration skills, communication skills, creativity, critical thinking skills, in- } \\
\text { formation technology skills, numeracy skills, problem-solving skills, self- } \\
\text { management skills, study skills). }\end{array}$ \\
\hline & Ln2 & $\begin{array}{l}\text { Compared to students of the same level in the past two academic years, my } \\
\text { students are more independent in their learning. }\end{array}$ \\
\hline & Ln3 & $\begin{array}{l}\text { Compared to students of the same level in the past two academic years, my } \\
\text { students are more active in constructing knowledge. }\end{array}$ \\
\hline & Ln4 & $\begin{array}{l}\text { Compared to students of the same level in the past two academic years, my } \\
\text { students are able to make better use of collaborative work to facilitate learn- } \\
\text { ing. }\end{array}$ \\
\hline \multirow{3}{*}{$\begin{array}{l}\text { Learning attitude: } \\
\text { motivation and } \\
\text { enthusiasm }\end{array}$} & Ln5 & $\begin{array}{l}\text { Compared to students of the same level in the past two academic years, my } \\
\text { students have more courage to express ideas in class. }\end{array}$ \\
\hline & Ln6 & $\begin{array}{l}\text { Compared to students of the same level in the past two academic years, my } \\
\text { students are motivated in their learning. }\end{array}$ \\
\hline & $\operatorname{Ln} 7$ & $\begin{array}{l}\text { Compared to students of the same level in the past two academic years, my } \\
\text { students enjoy learning more. }\end{array}$ \\
\hline
\end{tabular}

\section{Results}

Demographic data. Of the 1076 teachers coming from 130 schools, $56.3 \%$ were primary school teachers, while $43.7 \%$ were secondary school teachers. The sample consisted of relatively more female participants $(61.8 \%)$. Ages were in the range from 18-25 years old to over 50 years old, with the majority $(35.4 \%)$ at the age of $31-40$, and the minority (7.8\%) over 50. Teaching experience of the sample was of the range of below 3 years to over 20 years, and the majority (39.1\%) had 4-10 years of teaching experience. Overall, nearly half of the sample population (42.8\%) had a teaching experience of over 10 years.

Relationships. Reliability of the constructs was demonstrated by Cronbach alpha test using SPSS. As indicated from Table 6, all constructs had an alpha reliability greater than .07 , indicating that the items on the questionnaire were satisfactory in terms of internal consistency. Table 6 also shows the Pearson correlation coefficients among the five constructs. All of them had significant correlations with each other at the .01 level. Leadership had a high correlation with the school climate (.711), which indicated that leadership was likely to play a pivotal role in establishing a climate for collaboration and experimentation. School climate and ICT implementation were related to each other (.314), indicating the potential impact of school climate in shaping the collegial capacity of ICT implementation in schools. Compared to leadership and school climate, ICT implementation had a greater correlation with teaching and learning. This indicated that ICT implementation might have a more direct impact on teaching and learning. Teaching 
Table 6

Correlations among the Constructs of Leadership, Climate, ICT Implementation, Teaching, and Learning

\begin{tabular}{lccccc}
\hline & Leadership & Climate & ICT Implementation & Teaching & Learning \\
\hline Leadership & 1 & .711 & .264 & .300 & .289 \\
Climate & & 1 & .314 & .336 & .357 \\
ICT implementation & & & 1 & .356 & .361 \\
Teaching & & & & 1 & .584 \\
Learning & .813 & .776 & .720 & .700 & 1 \\
\hline Cronbach $\alpha$ & & & & & .879 \\
\hline
\end{tabular}

Note: All the correlation coefficients were obtained at the significance level of $p<.01$.

and learning were highly correlated with each other (.584), supporting that teaching had a direct impact on learning.

The correlation pattern delineated a possible route of impact for the five constructs (Fig. 2). The postulation was that a transformational leadership was highly influential in establishing a school climate for collaboration and experimentation that enhanced the collegial capacity of ICT implementation strategies, which in turn exhibited significant effect on teaching and on learning. From the high correlation between teaching and learning, it would also be possible that ICT implementation strategies exhibited its impact on learning if there was a change effected by ICT on teachers' pedagogy in classroom practices.

Impact of ICT on pedagogical changes. Immediately next to the individual questions comprising the construct of teaching, we had the construct of ICT in teaching asking

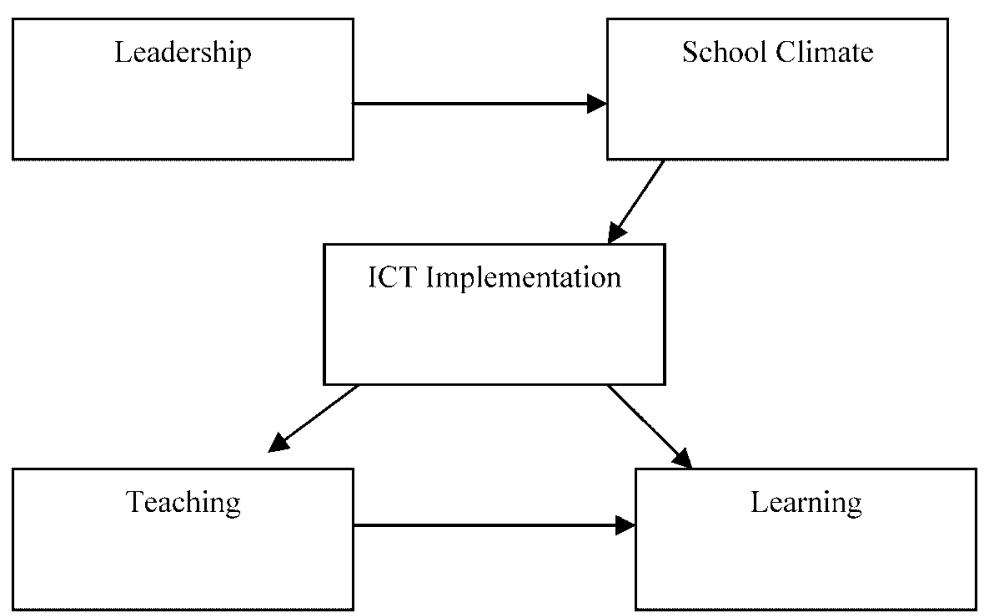

Fig. 2. A hypothesised model showing the pattern of relationships among the constructs in the ecology of ICT implementation in schools. 
whether the use of ICT facilitates the change that has been emerging for the past two years (Table 7). The results indicated that the implementation of ICT policy for teaching and learning has facilitated the shift to a more collaborative approach of lesson planning, and the use of ICT in teaching and learning has facilitated the shift from a traditional pedagogical approach to a more constructivist approach.

Impact of ICT on changes in learning. Results shown in Table 8 indicated that the use of ICT in teaching and learning has facilitated the shift from a traditional learning approach to a more active, and student-centred, learning approach. While the impact of ICT was most dominant in facilitating students in enjoying learning more (62\%) and in mastering generic skills $(61 \%)$, the impact was less significant in facilitating the shift in

Table 7

The construct of ICT in teaching probing the impact of ICT on facilitating changes in pedagogy

\begin{tabular}{|c|c|c|c|}
\hline Dimensions & Questions & Disagree $(\%)$ & Agree (\%) \\
\hline \multirow[t]{2}{*}{$\begin{array}{l}\text { Infusion of gene- } \\
\text { ric skills in cur- } \\
\text { riculum }\end{array}$} & $\begin{array}{l}\text { - Compared to the past two academic years, our school cur- } \\
\text { riculum is putting more emphasis on infusing generic skills } \\
\text { (e.g., critical thinking/creativity/ communication skills) } \\
\text { into teaching and learning of various subjects. }\end{array}$ & 18 & 82 \\
\hline & $\begin{array}{l}\text { - The use of ICT in teaching and learning facilitates the } \\
\text { above change that has been emerging for the past two years. }\end{array}$ & 30 & 70 \\
\hline \multirow{6}{*}{$\begin{array}{l}\text { A shift of peda- } \\
\text { gogical practices } \\
\text { to a more student- } \\
\text { centred approach }\end{array}$} & $\begin{array}{l}\text { - Compared to the past two academic years, I am creating } \\
\text { more opportunities for discussions to develop students' ex- } \\
\text { pressive and analytical abilities. }\end{array}$ & 17 & 83 \\
\hline & $\begin{array}{l}\text { - The use of ICT in teaching and learning facilitates the } \\
\text { above change that has been emerging for the past two years. }\end{array}$ & 41 & 59 \\
\hline & $\begin{array}{l}\text { - Compared to the past two academic years, I am encourag- } \\
\text { ing students to explore and to inquire in learning more. }\end{array}$ & 14 & 86 \\
\hline & $\begin{array}{l}\text { - The use of ICT in teaching and learning facilitates the } \\
\text { above change that has been emerging for the past two years. }\end{array}$ & 30 & 70 \\
\hline & $\begin{array}{l}\text { - Compared to the past two academic years, I am providing } \\
\text { more opportunities for students to determine their learning } \\
\text { activities. }\end{array}$ & 36 & 64 \\
\hline & $\begin{array}{l}\text { - The use of ICT in teaching and learning facilitates the } \\
\text { above change that has been emerging for the past two years. }\end{array}$ & 43 & 57 \\
\hline \multirow[t]{4}{*}{$\begin{array}{l}\text { Collaborative } \\
\text { teaching }\end{array}$} & $\begin{array}{l}\text { - Compared to the past two academic years, I am more will- } \\
\text { ing to have collaborative lesson preparation with my col- } \\
\text { leagues. }\end{array}$ & 30 & 70 \\
\hline & $\begin{array}{l}\text { - The implementation of ICT policy for teaching and learn- } \\
\text { ing facilitates the above change that has been emerging for } \\
\text { the past two years. }\end{array}$ & 41 & 59 \\
\hline & $\begin{array}{l}\text { - Compared to the past two academic years, I am more will- } \\
\text { ing to participate in peer classroom observation. }\end{array}$ & 31 & 69 \\
\hline & $\begin{array}{l}\text { - The implementation of ICT policy for teaching and learn- } \\
\text { ing facilitates the above change that has been emerging for } \\
\text { the past two years. }\end{array}$ & 49 & 51 \\
\hline
\end{tabular}


Table 8

The construct of ICT in learning probing the impact of ICT on facilitating changes in learning

\begin{tabular}{|c|c|c|c|}
\hline Dimensions & Questions & Disagree $(\%)$ & Agree (\%) \\
\hline \multirow[t]{8}{*}{$\begin{array}{l}\text { Learning ability: } \\
\text { generic skills and } \\
\text { active learning }\end{array}$} & $\begin{array}{l}\text { - Compared to students of the same level in the past two aca- } \\
\text { demic years, my students are more competent in mastering } \\
\text { various generic skills (e.g., collaboration skills, communica- } \\
\text { tion skills, creativity, critical thinking skills, information tech- } \\
\text { nology skills, numeracy skills, problem-solving skills, self- } \\
\text { management skills, study skills). }\end{array}$ & 35 & 65 \\
\hline & $\begin{array}{l}\text { - The use of ICT in teaching and learning facilitates the above } \\
\text { change that has been emerging for the past two years. }\end{array}$ & 39 & 61 \\
\hline & $\begin{array}{l}\text { - Compared to students of the same level in the past two aca- } \\
\text { demic years, my students are more independent in their learn- } \\
\text { ing. }\end{array}$ & 50 & 50 \\
\hline & $\begin{array}{l}\text { - The use of ICT in teaching and learning facilitates the above } \\
\text { change that has been emerging for the past two years. }\end{array}$ & 45 & 55 \\
\hline & $\begin{array}{l}\text { - Compared to students of the same level in the past two aca- } \\
\text { demic years, my students are more active in constructing } \\
\text { knowledge. }\end{array}$ & 54 & 46 \\
\hline & $\begin{array}{l}\text { - The use of ICT in teaching and learning facilitates the above } \\
\text { change that has been emerging for the past two years. }\end{array}$ & 49 & 51 \\
\hline & $\begin{array}{l}\text { - Compared to students of the same level in the past two aca- } \\
\text { demic years, my students are able to make better use of collab- } \\
\text { orative work to facilitate learning. }\end{array}$ & 40 & 60 \\
\hline & $\begin{array}{l}\text { - The use of ICT in teaching and learning facilitates the above } \\
\text { change that has been emerging for the past two years. }\end{array}$ & 47 & 53 \\
\hline \multirow[t]{6}{*}{$\begin{array}{l}\text { Learning attitude: } \\
\text { motivation and } \\
\text { enthusiasm }\end{array}$} & $\begin{array}{l}\text { - Compared to students of the same level in the past two aca- } \\
\text { demic years, my students have more courage to express ideas } \\
\text { in class. }\end{array}$ & 35 & 65 \\
\hline & $\begin{array}{l}\text { - The use of ICT in teaching and learning facilitates the above } \\
\text { change that has been emerging for the past two years. }\end{array}$ & 55 & 45 \\
\hline & $\begin{array}{l}\text { - Compared to students of the same level in the past two aca- } \\
\text { demic years, my students are more motivated in their learning. }\end{array}$ & 45 & 55 \\
\hline & $\begin{array}{l}\text { - The use of ICT in teaching and learning facilitates the above } \\
\text { change that has been emerging for the past two years. }\end{array}$ & 48 & 52 \\
\hline & $\begin{array}{l}\text { - Compared to students of the same level in the past two aca- } \\
\text { demic years, my students are enjoying learning more. }\end{array}$ & 38 & 62 \\
\hline & $\begin{array}{l}\text { - The use of ICT in teaching and learning facilitates the above } \\
\text { change that has been emerging for the past two years. }\end{array}$ & 38 & 62 \\
\hline
\end{tabular}

active expression of ideas (45\%), and the shift in active construction of knowledge (51\%). Possibly, the use of ICT in facilitating such kinds of learning demands more effort and skills from teachers.

Impact of ICT on instructional strategies. To explore the impact of ICT on instructional strategies of teachers, two questions were asked:

1. The following instructional strategies are used in my practice: 
2. Which of the following instructional strategies has/have been reinforced by your using of ICT?

(The choices of instructional strategies are: exposition, project-based learning, inductive teaching, peer tutoring, inquiry learning, problem-based learning, collaborative learning, individual learning, others.)

Results shown in Table 9 indicated that teachers used a diversified mode of instructional strategies including non-traditional ones. It is not surprising that exposition (90\%) was still the most dominating instructional strategy. However, it is noteworthy that a number of 'non-traditional' instructional strategies were emerging, such as project-based learning (66\%), inquiry learning (44\%) and collaborative learning (44\%). The results further revealed that teachers found ICT useful in reinforcing the emerging practices. A greater majority of teacher regarded ICT as useful in reinforcing their use of projectbased learning $(67 \%)$, while only a minority regarded ICT as useful in reinforcing their use of peer tutoring (16\%) and inductive teaching (17\%). The difference in percentages for an instructional strategy was calculated by subtracting the percentage in terms of current use from that of being reinforced by using ICT, and a zero or positive difference would indicate that ICT was effective in enhancing the instructional strategy. Accordingly, it seems that ICT was effective in enhancing project-based learning, inquiry learning, problem-based learning, and individual learning. Further, the greatest proportions of teachers $(31 \%)$ who were using exposition did not find ICT useful in reinforcing the instruction.

In the analysis, for each of the instructional strategy being reinforced by using of ICT, teachers were divided into two groups: those who indicated instructional strategy as being reinforced by using of ICT, and those who did not. An independent sample t-test was conducted to compare the mean score of changes in learning (the learning construct) between the "yes" and the "no" groups of teachers. Other than statistical significance, the

Table 9

Results showing the impact of ICT on instructional strategies

\begin{tabular}{lrrrrr}
\hline Instructional strategies & $\begin{array}{r}\text { Currently used in } \\
\text { teachers' practice (\%) }\end{array}$ & $\begin{array}{r}\text { Reinforced by using } \\
\text { ICT (\%) }\end{array}$ & Differences in \% \\
\hline Exposition & 990 & $(90 \%)$ & 651 & $(59 \%)$ & $-31 \%$ \\
Project-based learning & 729 & $(66 \%)$ & 736 & $(67 \%)$ & $1 \%$ \\
Inductive teaching & 341 & $(31 \%)$ & 188 & $(17 \%)$ & $-14 \%$ \\
Peer tutoring & 391 & $(35 \%)$ & 173 & $(16 \%)$ & $-19 \%$ \\
Inquiry learning & 491 & $(44 \%)$ & 483 & $(44 \%)$ & $0 \%$ \\
Problem-based learning & 273 & $(25 \%)$ & 267 & $(24 \%)$ & $-1 \%$ \\
Collaborative learning & 482 & $(44 \%)$ & 348 & $(31 \%)$ & $-2 \%$ \\
Individual learning & 543 & $(49 \%)$ & 314 & $(47 \%)$ & $0 \%$ \\
Others & 3 & $(0.3 \%)$ & 3 & $(0.3 \%)$ & 0 \\
\hline
\end{tabular}

Note: Subjects are allowed to choose multiple options. 
importance of the findings was also assessed with the effect size. The effect size is a set of statistics which indicate the relative magnitude of the differences between the means, and the most common one is eta squared, and an eta squared value of .01 indicates a small effect (Pallant, 2001). As shown in Table 10, in comparison with their counterpart, teachers who considered inductive teaching, inquiry learning, problem-based learning, and collaborative learning as being reinforced by using of ICT had a statistically significant difference in the mean score for changes in learning, though the actual difference was small as indicated by the small eta squared value of 0.01 . On the whole, the traditional instructional strategies being reinforced by ICT like exposition, peer tutoring, and individual learning have no effect on the mean score of changes in learning. On the other hand, nearly all the non-traditional instructional strategies being reinforced by ICT raised the mean score for changes in learning, except project-based learning. Specifically, in comparison with teachers who didn't, teachers who indicated that ICT had reinforced their use of non-traditional strategies of inductive teaching, inquiry learning, problembased learning, and collaborative learning, had a little higher mean score of changes in learning.

Effect of frequency of ICT use in classroom teaching on changes in learning. As indicated in Table 11, the majority of teachers (over 50\%) had the frequency of 1 to 5 hours per week of ICT use in classroom teaching, and only a very small proportion of teachers (7\%) had the frequency of over 10 hours per week of ICT use in classroom teaching. On

Table 10

T-test results showing the effect of instructional strategies that have been reinforced by using of ICT on the index of changes in learning

\begin{tabular}{|c|c|c|c|}
\hline \multirow{2}{*}{\multicolumn{2}{|c|}{$\begin{array}{l}\text { Instructional strategies that have been } \\
\text { reinforced by using of ICT ( } n=\text { count) }\end{array}$}} & \multicolumn{2}{|c|}{ Changes in learning } \\
\hline & & \multirow{2}{*}{$\begin{array}{c}\text { Mean (Eta squared) } \\
2.58\end{array}$} & \multirow{2}{*}{$\begin{array}{c}\text { Standard deviation } \\
0.45\end{array}$} \\
\hline Exposition & Yes (635) & & \\
\hline & No (445) & 2.56 & 0.44 \\
\hline \multirow[t]{2}{*}{ Project-based learning } & Yes (725) & 2.58 & 0.45 \\
\hline & No (358) & 2.56 & 0.42 \\
\hline \multirow[t]{2}{*}{ Inductive teaching } & Yes (184) & $2.69 * *(.01)$ & 0.44 \\
\hline & No (899) & $2.55^{* *}$ & 0.44 \\
\hline \multirow[t]{2}{*}{ Peer tutoring } & Yes (170) & 2.61 & 0.48 \\
\hline & No (913) & 2.57 & 0.43 \\
\hline \multirow[t]{2}{*}{ Inquiry learning } & Yes (674) & $2.62 * *(.01)$ & 0.42 \\
\hline & No (609) & 2.54 & 0.46 \\
\hline \multirow[t]{2}{*}{ Problem-based learning } & Yes (263) & $2.66 * *(.01)$ & 0.47 \\
\hline & No $(820)$ & $2.55^{* *}$ & 0.43 \\
\hline \multirow[t]{2}{*}{ Collaborative learning } & Yes (343) & $2.65 * *(.01)$ & 0.43 \\
\hline & No $(740)$ & $2.54 * *$ & 0.44 \\
\hline \multirow[t]{2}{*}{ Individual learning } & Yes (507) & 2.60 & 0.45 \\
\hline & No (576) & 2.55 & 0.44 \\
\hline
\end{tabular}

$* *$ the difference in mean scores is statistically significant at the .01 level 
the other hand, quite a substantial proportion of the teachers $(24 \%)$ were shown to be infrequent ICT users with a frequency of below 1 hour per week of ICT use in classroom teaching.

ANOVA results (Table 11) showed that there was a statistically significant difference at the $p<.05$ level in the mean score of changes in learning (the learning construct) among the various groups of teachers having different frequency of ICT use in classroom teaching. Post-hoc comparisons using the Tukey HSD test indicated that the mean score of changes in learning for the group with frequency of below 1 hour per week $(M=2.49$, $S D=0.42$ ) was significantly lower than the mean score for the group with frequency of $1-5$ hours per week $(M=2.60, S D=0.44)$, and the mean score for the group with frequency $6-10$ hours per week $(M=2.64, S D=0.46)$. Mean score for changes in learning for the group with frequency of over 10 hours per week $(M=2.54, S D=$ 0.47 ) did not differ significantly from that of the other groups. The effect size, calculated using eta squared, was 0.02. Despite reaching statistical significance, the actual difference in mean scores for changes in learning across the 3 groups was small. In other words, frequency of ICT use in classroom teaching exerted a small effect on the mean scores for changes in learning. Specifically, in comparison with teachers with 6-10 hours per week and 11-15 hours per week of ICT use in classroom teaching, teachers with less than 1 hour per week of ICT use in classroom teaching had a little lower mean score of changes in learning.

Effect of types of commonly used ICT tools on changes in learning. As shown in Table 12, of the seven types of ICT tools, the most commonly used ones were Internet and presentation software, while the least commonly used ones were simulation software, drill-and-practice software, and software for constructing knowledge. Meanwhile, communication software and web-based course platform were found to be fairly commonly used ICT tools. Teachers were asked to choose among the seven types of ICT tools the two most commonly used ones. In the analysis, for each of the commonly used ICT tools, teachers were divided into two groups: those who indicated the software as the most commonly used ICT tools, and those who did not. An independent sample t-test was conducted to compare the mean score of changes in learning between the "yes" and the "no" groups of teachers. As shown in Table 12, in comparison with teachers who

Table 11

ANOVA results showing the effect of frequency of ICT use in classroom teaching on the index of changes in learning

\begin{tabular}{lcc}
\hline \multirow{2}{*}{$\begin{array}{c}\text { Frequency of ICT use in } \\
\text { classroom teaching }(n=\text { count })\end{array}$} & Mean (Eta squared) & Standard deviation \\
\cline { 2 - 3 } Below 1 hour per week $(n=255)$ & $2.49 *(0.02)$ & 0.41 \\
$1-5$ hours per week $(n=574)$ & $2.60 *$ & 0.44 \\
6-10 hours per week $(n=162)$ & $2.64 *$ & 0.46 \\
Over 10 hours per week $(n=78)$ & 2.54 & 0.48 \\
\hline
\end{tabular}

* the difference in mean scores is statistically significant at the .05 level 
Table 12

T-test results showing the effect of the most common types of ICT tools used on the index of changes in learning

\begin{tabular}{|c|c|c|c|}
\hline \multirow{2}{*}{\multicolumn{2}{|c|}{$\begin{array}{l}\text { The most common types of ICT } \\
\text { tools used ( } n=\text { count })\end{array}$}} & \multicolumn{2}{|c|}{ Changes in learning } \\
\hline & & \multirow{2}{*}{$\frac{\text { Mean (Eta squared) }}{2.58}$} & \multirow{2}{*}{$\frac{\text { Standard deviation }}{0.44}$} \\
\hline Internet & Yes $(n=848)$ & & \\
\hline & No $(n=235)$ & 2.57 & 0.45 \\
\hline \multirow[t]{2}{*}{ Presentation software } & Yes $(n=790)$ & 2.58 & 0.45 \\
\hline & No $(n=293)$ & 2.58 & 0.43 \\
\hline \multirow[t]{2}{*}{ Communication software } & Yes $(n=286)$ & 2.60 & 0.43 \\
\hline & No $(n=797)$ & 2.57 & 0.44 \\
\hline \multirow[t]{2}{*}{ Web-based course platform } & Yes $(n=188)$ & $2.70 * *(0.02)$ & 0.45 \\
\hline & No $(n=895)$ & $2.55^{* *}$ & 0.44 \\
\hline \multirow[t]{2}{*}{ Simulation software } & Yes $(n=78)$ & 2.50 & 0.46 \\
\hline & No $(n=1005)$ & 2.58 & 0.44 \\
\hline \multirow[t]{2}{*}{ Drill-and-practice software } & Yes $(n=69)$ & 2.54 & 0.51 \\
\hline & No $(n=1014)$ & 2.58 & 0.44 \\
\hline \multirow[t]{2}{*}{ Software for constructing knowledge } & Yes $(n=69)$ & $2.72 * *(0.01)$ & 0.48 \\
\hline & No $(n=1014)$ & $2.57 * *$ & 0.44 \\
\hline
\end{tabular}

Notes: i) Subjects were allowed to choose 2 options out of the 7 types of ICT tools; and

ii) $* *$ the difference in mean scores is statistically significant at the .01 level.

didn't, teachers who indicated web-based course platform and software for constructing knowledge as the most commonly used ICT tools had a statistically significant difference at the $p<.05$ level in the mean score for changes in learning (the learning construct), though the actual difference was small as indicated by the small eta squared value of .02. In general, it was found that most of the commonly used ICT tools exert no effect on the mean score for changes in learning, except the web-based course platform and software for constructing knowledge. Specifically, teachers who indicated the web-based course platform and software for constructing knowledge as the most commonly used ICT tools had a little higher mean score of changes in learning than those of their counterparts.

Sustaining an on-going development of ICT in teaching and learning. It is encouraging to see that ICT has initiated changes in teaching and learning, but it is equally important to tease out the factors to sustain such changes. In this respect, teachers were asked to choose 4 options out of 11 options that they considered most important in sustaining an on-going development of ICT in teaching and leaning in their schools, and they were also asked to indicate whether their schools had established the 11 conditions. Results in Table 13 revealed that the practical conditions were of higher concern to teachers. These included continuous funding, ongoing staff development pertaining to ICT in education, appropriate allocation of resources, and provision of software that is suitable for school's curricula. However, the majority of teachers (over 60\%) indicated that their school had not established these practical conditions, except the ongoing staff development pertaining to ICT in education. On the whole, the greatest majority of teachers $(51 \%)$ indicated that their schools had established ongoing staff development pertaining to ICT in educa- 
Table 13

Frequencies showing the conditions teachers considered ost important in sustaining an on-going development of ICT in teaching nd leaning in their schools, and the conditions that have been stablished by their schools

\begin{tabular}{|c|c|c|}
\hline \multirow{2}{*}{$\begin{array}{l}\text { Conditions that sustain an ongoing development of } \\
\text { ICT in teaching and learning }\end{array}$} & \multicolumn{2}{|c|}{ Count (percentage) } \\
\hline & $\begin{array}{l}\text { Considered as } \\
\text { most important }\end{array}$ & $\begin{array}{l}\text { Established } \\
\text { by the school }\end{array}$ \\
\hline Continuous funding & $622(56 \%)$ & $364(33 \%)$ \\
\hline Ongoing staff development pertaining to ICT in education & $588(53 \%)$ & $565(51 \%)$ \\
\hline Appropriate allocation of resources & $565(51 \%)$ & $405(37 \%)$ \\
\hline Provision of software that is suitable for school's curricula & $532(48 \%)$ & $278(25 \%)$ \\
\hline A school culture that welcomes collegial ICT exchange & $403(36 \%)$ & $383(35 \%)$ \\
\hline A plan to integrate ICT into curriculum & $356(32 \%)$ & $232(21 \%)$ \\
\hline A school culture that welcomes innovation and risk taking & $345(31 \%)$ & $338(31 \%)$ \\
\hline $\begin{array}{l}\text { Shared vision on teaching and learning among teachers and } \\
\text { students }\end{array}$ & $290(26 \%)$ & $198(18 \%)$ \\
\hline $\begin{array}{l}\text { A leadership to appropriately evaluate the school's capacities } \\
\text { and readiness for implementing ICT innovations }\end{array}$ & $227(21 \%)$ & $174(16 \%)$ \\
\hline $\begin{array}{l}\text { A mechanism to manage and disseminate ICT resources for } \\
\text { teaching and learning }\end{array}$ & $103(9 \%)$ & $124(11 \%)$ \\
\hline A change in modes of assessment in public examinations & $91(8 \%)$ & $24(2 \%)$ \\
\hline Others & $14(1 \%)$ & $21(2 \%)$ \\
\hline
\end{tabular}

Notes: Subjects are allowed to choose 4 out of the 12 options.

tion. Around one third of teachers indicated that their schools had established continuous funding, appropriate allocation of resources, a school culture that welcomes collegial ICT exchange, and a school culture that welcomes innovation and risk taking. Notably, only a minor proportion of teachers $(8 \%)$ regarded a change in modes of assessment in public examinations as most important in sustaining an ongoing development of ICT in teaching and learning. Likewise, only $2 \%$ teachers indicated that their schools had changed the modes of assessment.

\section{Conclusion}

Leadership has been shown to have pivotal effect on establishing the school climate, which is likely to have impact on shaping the ICT implementation in schools. The collegial capacity of ICT implementation strategies is hypothesised to play a role of facilitating the shift of teachers' pedagogical practice from a traditional approach to a constructivist one, and to a more collaborative approach of lesson planning. There have been a number of 'non-traditional' instructional strategies emerging, such as project-based learning, inquiry learning, and collaborative learning. The shift in pedagogical approach has been provoking a shift in students' learning attitudes toward the side of student-centred learning. On average, teachers perceived a greater paradigm shift in learning among their students if they regarded ICT as useful in reinforcing inductive teaching, inquiry learning, 
problem-based learning, and collaborative learning, but not in reinforcing project-based learning. The change has been emerging, but it seems that it still takes some more time for the use of ICT to facilitate a more significant change in the active construction of knowledge and expression of ideas among students.

At the level of daily classroom practice, paradigm shift in learning still will not happen simply by using more ICT. Successful paradigm shift in learning requires the combination of the regular ICT use in classroom teaching (on average teachers with below one hour of ICT use in classroom teaching perceived a smaller paradigm shift in learning among their students) with the appropriate kinds of instructional strategies (nearly all the non-traditional instructional strategies being reinforced by ICT raised the mean score for changes in learning, except project-based learning) being reinforced by the appropriate types of ICT tools used (on average teachers who used web-based course platform or software for constructing knowledge perceived a greater paradigm shift in learning among their students). In enhancing a paradigm shift to student-centred learning, explicit attention has to be given to the acquisition of higher-order thinking and problem-solving skills. Results of the present study indicated that teachers who thought that ICT reinforced inductive teaching, inquiry learning, problem-based learning, and collaborative learning were more inclined to do so. On the other hand, the majority of teachers who regarded ICT as useful in enhancing project-based learning might have difficulties in structuring their tasks to provide more opportunities for students to discuss and learn with understanding. Web-based course platform and software for constructing knowledge were appropriate ICT tools that might help in this respect.

To sustain the changes, most teachers believed that it was necessary to have continuous funding, ongoing staff development pertaining to ICT in education, appropriate allocation of resources, and the provision of suitable software. Most schools have not yet established these conditions, except the condition of ongoing staff development pertaining to ICT in education. While it is encouraging to see that quite a lot of teachers find their school providing ongoing staff development pertaining to ICT in education, it is still worth pausing to consider the focus of future staff development, and see how teachers are better supported in using ICT to facilitate students to construct knowledge and express ideas.

\section{Acknowledgment}

This paper was part of the results of a research project $(H K B U$ 2034/02H) funded by the Research Grants Council of Hong Kong Special Administration Region of People's Republic of China, the support of which has been much appreciated.

\section{References}

Bober, M.J. (2002). Technology integration: The difficulties inherent in measuring pedagogical change. TechTrends, 46(1), 21-23. 
Centre for Information Technology in School and Teacher Education, University of Hong Kong (2002). Preliminary Study on Reviewing the Progress and Evaluating the Information Technology in Education Projects, December 2000 to August 2001. Hong Kong.

Cheng, Y.C. (2002). The changing context of school leadership: Implications for paradigm shift. In P. Hallinger (Ed.), Second International Handbook of Educational Leadership and Administration. Kluwer Academic Publishers, Dordrecht, Boston, London.

Curriculum Development Council (2001). The Way Forward in Curriculum Development: Learning to Learn, Life-Long Learning and Whole-Person Development. HK Government Press, Hong Kong.

Dexter, S.L., R.E. Anderson and H.J. Becker (2000). Teachers' views of computers as catalysts for changes in their teaching practice. Journal of Research on Computing in Education, 31(3), 221-239.

Education and Manpower Bureau (1998). Information Technology for Learning in a New Era Five-Year Strategy 1998/99 to 2002/03. Hong Kong Government, Hong Kong.

Ferneding, K. A. (2003). Questioning Technology: Electronic Technologies and Educational Reform. Peter Lang, New York, Washington, D.C.

Freiberg, H.J., and T.A. Stein (1999). Measuring, improving and sustaining healthy learning environments. In H.J. Freiberg (Ed.), School Climate: Measuring, Improving and Sustaining Healthy Learning Environments. Falmer Press, London, Philadelphia.

Fullan, M. (1993). Change Forces: Probing the Depths of Educational Reform. Falmer Press, London, New York.

Fullan, M. (1995). The school as a learning organisation: Distant dreams. Theory into Practice, 34(4), 230-235.

Hall, G.E. (1995). The local educational change process and policy implementation. In M.H. O’Neill (Ed.), International Perspectives on Educational Reform and Policy Implementation. Falmer Press, London, Washington.

Hall, G.E., and D.S.G. Carter (1995). Implementing change in the 1990s: Paradigms, practices and possibilities. In M.H. O'Neill (Ed.), International Perspectives on Educational Reform and Policy Implementation. Falmer Press, London, Washington.

Hallinger, P., and R.H. Heck (1998). Exploring the principal's contribution to school effectiveness: 1980-1995. School Effectiveness and School Improvement, 9(2), 157-179.

Honey, M., K.M. Culp and F. Carrigg (1999). Perspectives on technology and education research: Lessons from the past and present. Paper presented at the Secretary's Conference on Education Technology. Washington, D.C.

Honey, M., K.M. Culp and F. Carrigg (2000). Perspectives on technology and education research: Lessons from the past and present. Journal of Educational Computing Research, 23(1), 5-14.

Lankshear, C., I. Snyder and B. Green (2000). Teachers and Technoliteracy: Managing Literacy, Technology and Learning in Schools. Allen \& Unwin, St Leonards, NSW.

Leithwood, K. (1994). Leadership for school restructuring. Educational Administration Quarterly, 30(4), 498518.

Leithwood, K., and D.L. Duke (1999). A century's quest to understand school leadership. In K.S. Louis (Ed.), Handbook of Research on Educational Administration: A Project of the American Educational Research Association, 2nd ed. Jossey-Bass Publishers, San Francisco.

Marks, H.M., and S.M. Printy (2003). Principal leadership and school performance: An integration of transformational and instructional leadership. Educational Administration Quarterly, 39(3), 370-397.

McLaughlin, M. W. (1991). Learning from experience: Lessons from policy implementation. In A.R. Odden (Ed.), Education Policy Implementation. State University of New York Press, Albany.

Ogawa, R.T., and S.T. Bossert (1995). Leadership as an organisational quality. Educational Administration Quarterly, 31(2), 224-243.

Oppenheimer, T. (2003). The Flickering Mind: The False Promise of Technology in the Classroom and How Learning Can Be Saved. Random House, New York.

Pallant, J. (2001). SPSS Survival Manual: A Step by Step Guide to Data Analysis Using SPSS for Windows (version 10). Open University, Buckingham, Philadelphia.

Panel On Education Technology (1997). Report to the president on the use of technology to strengthen K-12 education in the United States. U.S. Government Printing Office, Washington, DC.

Papert, S. (1997). Why school reform is impossible. The Journal of the Learning Sciences, 6(4), 417-427.

Reinhartz, J., and D.M. Beach (2004). Educational Leadership: Changing Schools, Changing Roles. Pearson, Boston. 
Senge, P.M., N. Cambron-McCabe, T. Lucas, B. Smith, J. Dutton and A. Kleiner (2000). Schools that Learn: A Fifth Discipline Fieldbook for Educators, Parents, and Everyone Who Cares about Education. Doubleday, New York.

Zhao, Y., and K.A. Frank (2003). Factors affecting technology use in schools: An ecological perspective. American Educational Research Journal, 40(4), 807-840.

E.M.L. Wong is currently a $\mathrm{PhD}$ candidate at the Hong Kong Baptist University, and formerly a secondary school teacher. She has been the project manager of a research project "Comparative Studies of ICT in Education in Hong Kong and Singapore" funded by the Research Grant Council of the Hong Kong SAR government. Her research interests are ICT in education, educational leadership, and educational change.

S.C. Li received a BSc (Hons) in 1984 from the University of Hong Kong and Postgraduate Certificate in Education in subsequent years from the same university. He received his $\mathrm{PhD}$ in theoretical nuclear and particle physics in 1996 from the Australian National University. He was a secondary school teacher in Hong Kong for eight years before pursuing his $\mathrm{PhD}$ degree. He was a postdoctoral research fellow in ANU, working in the area of computer simulation and modelling of protein dynamics. He subsequently joined the Centre for Information Technology in Education of the Faculty of Education of the University of Hong Kong as the deputy director from 1998-2001. He is currently an associate professor and also the course coordinator of the full-time Postgraduate Diploma in Education programme of Department of Education Studies at Hong Kong Baptist University. He has been the principal investigator of a number of research projects in the area of IT in education, funded by the Competitive Earmarked Research Grant Committee and the HKSAR government. 


\title{
Ar IKT lems švietimo pokyčius? IKT poveikio mokymui ir mokymuisi Honkonge tyrimas
}

\author{
Emily M. L. WONG, Sandy C. LI
}

Nenutrūkstamas ir beprecedentis informaciniu ir komunikaciniu technologiju (IKT) tobulejjimas, lydimas ekonominès globalizacijos, kelia milžinišką iššūkị švietimui. Spartus IKT diegimo švietime augimas suinteresuotąsias puses stato akistaton su šių technologiniu priemonių poveikiu ir veiksmingumu. Straipsnyje nagrinejjamas IKT poveikis Honkonge gyvuojančiai mokymo praktikai, atsižvelgiant i pokyčius, susijusius su ịvairiomis vyriausybės skatintomis informacinių technologijų iniciatyvomis, kurios ypač koncentravosi ties mokytojais. Taip pat tiriama, kaip ši mokymo praktika dera su įvairiais kontekstiniais veiksniais, pavyzdžiui, su lyderyste ar mokykliniu klimatu. Siekiant pagilinti supratimą apie tai, kokị vaidmenį studentu mokymosi procese atlieka IKT, straipsnyje nagrinejamos sąsajos tarp pokyčiu mokymesi ir ivairiu kitu veiksniu, pavyzdžiui, IKT priemonių tipu panaudojimo pamokose ir šio panaudojimo dažnumo ar skirtingu mokymo strategiju. Tikimasi, jog tyrimo rezultatai pasitarnaus švietimo praktikus ir tyrinėtojus supažindinant su naujomis su IKT susijusiomis pedagoginėmis praktikomis. 